\title{
CONVERSION OF VARIOUS ORGANIC WASTES INTO VALUABLE MATERIALS USING SUBCRITICAL WATER TREATMENT REACTORS
}

\author{
NAOKO NAKAGAWA ${ }^{1}$, NORIO SUGIURA ${ }^{2}$, MOTOO UTSUMI ${ }^{2}$, \\ KAZUYA SHIMIZU² \& TOMONAO MIYASHIRO ${ }^{3}$ \\ ${ }^{1}$ Department of Physics, Rikkyo University, Japan \\ ${ }^{2}$ Faculty of Life \& Environmental Sciences, University of Tsukuba, Japan \\ ${ }^{3}$ G-8 INTERNATIONAL TRADING Co., Ltd., Japan
}

\begin{abstract}
The "Basic Law for Promoting a Recycling-based Society" was promulgated as a framework for the formation of a recycling-oriented society in 2000 with the aim of creating economic sustainable development while striving for both environmental preservation and social equity. Sewage sludge, animal fecal matter as well as garbage are difficult wastes for any developing or developed society to process. In order to solve these waste problems, the subcritical water treatment (SCWT) technology was developed. In this study, pilot experiments with sewage sludge, livestock manure and fishery waste were undertaken using the SCWT reactor by varying the temperature from $100^{\circ} \mathrm{C}-200^{\circ} \mathrm{C}$, the pressure 1.0 MPa-2.0 MPa and limiting the time of operation to 60 minutes. The chemical analysis of the treated samples gave results appropriate for a fertilizer. For example, the resulting analysis for the treated sewage sludge was: water content $60.97 \%$, $\mathrm{pH} 4.16$, organic content $87.33 \%$, T-N $0.69 \%, \mathrm{P}_{2} \mathrm{O}_{5} 0.705 \%$, $\mathrm{K} 3,150 \mathrm{mg} / \mathrm{kg}$, Ca 70,500 mg/kg, Mg 3,090 mg/kg, and Na 1,150 mg/kg. These results indicate good elements for a general organic fertilizer as it was verified to be pathogen free, as well as free of hazardous chemicals for continuous applications on agricultural lands. Thus, it was verified that the SCWT technology is useful for producing valuable resources from organic wastes.

Keywords: fishery waste, feed, fertilizer, organic wastes, resources, subcritical water treatment.
\end{abstract}

\section{INTRODUCTION}

Aiming for sustainable development while striving for both environmental preservation and economic development, the "Basic Law for Promotion of a Recycling-based Society" [1] was promulgated in Japan as a framework for the formation of a recycling-oriented society in 2000. Since then, the social interest in environmental problems has risen and the development of individual laws is progressing. For this reason, the effective use of these unused resources and the development of high value-added technology are important issues in the production area.

For example, in recent years, using treated sewage sludge biosolids for agriculture was also considered as a new direction for sewage treatment policy. Importantly the collection of the valuable resource of phosphorus from sewage is to be implemented in collaboration with the Ministry of Agriculture, Forestry and Fisheries of Japan because the price of fertilizer is rising due to a shortage of phosphorus worldwide [2]. Sewage systems discharge large amounts of sewage sludge. This sewage sludge is treated by a variety of technologies before disposal to avoid environmental and health risks that are caused by pathogens, hazardous chemicals and heavy metals. When the safety of biosolids from treated sewage sludge is ensured it becomes a valuable organic resource for recycling. However, many of the conventional treatment methods and processes are costly, using significant levels of energy.

In addition, the fisheries industry's efforts towards the establishment of a recycling-based society have progressed. Fifty five percent of a fish can be eaten, but the remaining $45 \%$ includes the head, spines, and abdomen which cannot be eaten, so these are generally 
disposed of by incineration. However, the fish residue contains high amounts of unsaturated fatty acids such as DHA (docosahexaenoic acid) and EPA (eicosapentaenoic acid). These are health foods which are effective for lowering cholesterol and neutralizing fat, and because it has an anticoagulant effect on blood for thrombus prevention as well

With the high importance being placed on recycling systems, a subcritical water treatment (SCWT) technology was developed (Fig. 1 and Fig. 2). The characteristics of the SCWT technology is that it can process any kind of organic wastes with a wide range of water content by a liquid mixed reaction using steam at a high temperature and pressure. There is no incineration process; therefore, this technology does not generate carbon dioxide, dioxin, or nitrous oxide. In addition, an offensive odor is not generated because of the sealed process.

In this study, demonstration experiments with sewage sludge, livestock manure, and fishery waste were undertaken using the SCWT reactor by varying temperature, pressure, and time. Therefore, a range of conditions for treatment of these wastes were found and the content of the treated samples were analyzed.

\section{SUBCRITICAL WATER TREATMENT (SCWT) TECHNOLOGY}

The key principle of the SCWT is that it only uses high pressure steam to process organic waste. When the temperature and the pressure of water are raised to $374^{\circ} \mathrm{C}$ and $22 \mathrm{MPa}(220$ atmospheres), it becomes a uniform fluid that is neither steam nor water. This condition is called the critical point. When the temperature and pressure are lower than the critical point the water is called subcritical water, and a hydrolysis reaction can occur with this subcritical water. Through this reaction, the organic molecules such as cellulose, starch, protein and lignin are decomposed into respectively, polysaccharides, glucose, amino acids and phenols as well as being changed into a liquid form from solids (Fig. 1).

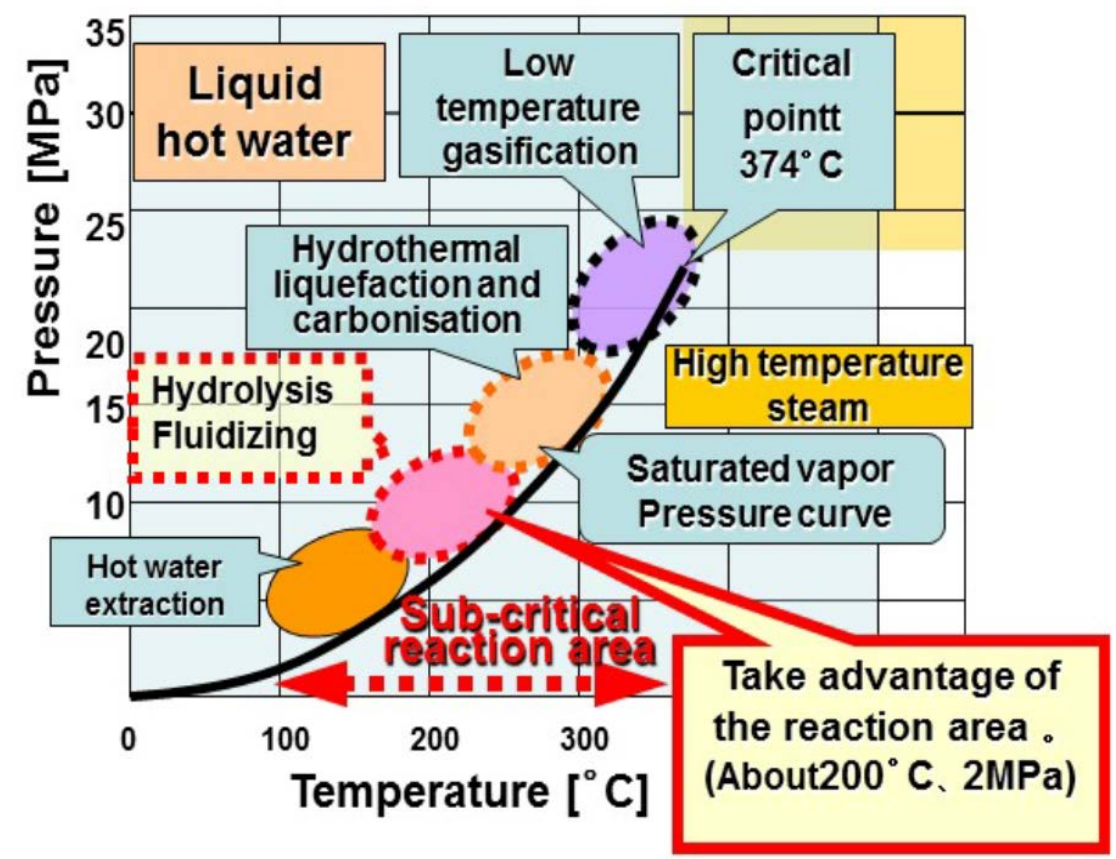

Figure 1: Principal of the subcritical water treatment technology. 


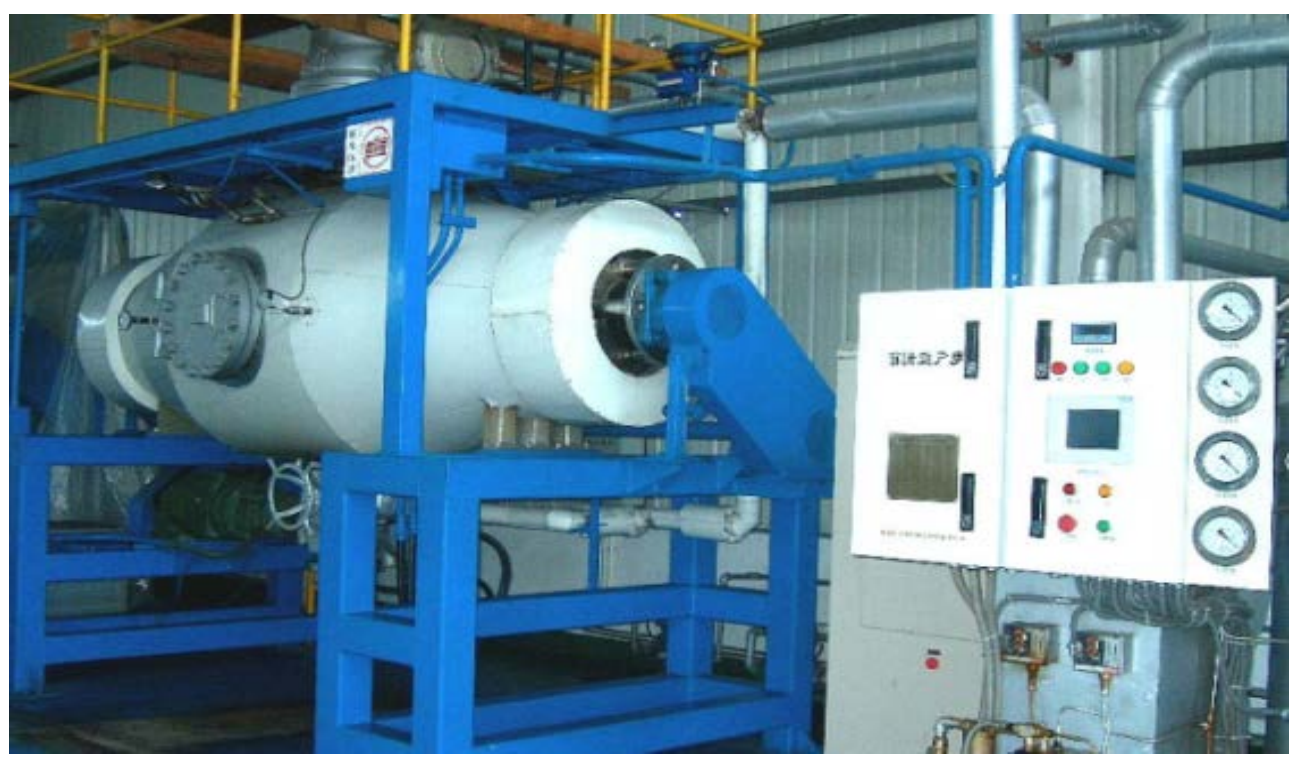

Figure 2: Subcritical water treatment reactor.

Fig. 2 shows the batch style SCWT reactor that processes combustible waste by using high pressure and high temperature in a pressurized vessel. The dimensions are $4.5 \mathrm{~m}$ in height, $8 \mathrm{~m}$ in length, and $2.5 \mathrm{~m}$ in width. Processing $2 \mathrm{~m}^{3}$ of waste takes about an hour. It has the advantage of being able to process various types of organic waste to obtain valuable residual products so that the process could be called a multipurpose recycling system of resources. The SCWT reactor has low construction costs as well as low operation costs, which are about $1 / 5$ of that of current incineration processes. The choice of location is easy because there is no requirement for waste water treatment. Drained steam water is a liquid fertilizer. Drained water from the reactor is also a liquid fertilizer.

The batch type SCWT reactors with a volume of $2 \mathrm{~m}^{3}$ are installed in Japan, China and Taiwan and these were used for the demonstration experiments. The boiler capacity for these installations was $500 \mathrm{~kg} / \mathrm{h}$. The wastes used in the demonstration experiments were sewage sludge and pig manure in China, chicken excreta in Taiwan, and fishery waste in Japan.

\section{EXPERIMENTAL PROCEDURE}

For most organic material treatment, the temperature for the hydrolysis reaction in the subcritical water domain is $100-200^{\circ} \mathrm{C}$ and the pressure of the saturated vapor is $1.0-2.0 \mathrm{MPa}$. If the temperature and pressure conditions are higher than these, a degradation of organic material and loss of organic nutrients occurs. Therefore, the temperature was set between $100-200^{\circ} \mathrm{C}$. The SCWT was processed automatically with a program of steam injection to satisfy the pre-determined temperature and pressure conditions. The reaction time ranged from 15 to 30 minutes. After the reactor steam vapor was degassed, the reactor was stabilized to normal pressure and the processed materials were discharged. Content analyses were performed on the sewage sludge, livestock manure and fishery waste used for the demonstration experiments as well as on the products following treatment by the SCWT. 


\section{RESULTS AND DISCUSSION}

The sewage sludge, pig manure, chicken excreta, and fishery waste before and after the SCWT are shown in Fig. 3. The fishery waste, shown in Fig. 3. was treated with a temperature of $140^{\circ} \mathrm{C}$, a pressure of $1.0 \mathrm{MPa}$, and the reaction time was set to 10 minutes. The sewage sludge was treated with a temperature of $185^{\circ} \mathrm{C}$, a pressure of $1.2 \mathrm{MPa}$, and the reaction time was set to 30 minutes. Pig manure and chicken excreta were treated with similar operating conditions. The SCWT treated materials were piled on a concrete floor for natural aerobic fermentation in the factory. In Fig. 4. chicken excreta is shown partly covered by a white patch of actinomyces growth after treatment. It was found that natural fermentation occurred without inoculation of any specific bacteria.

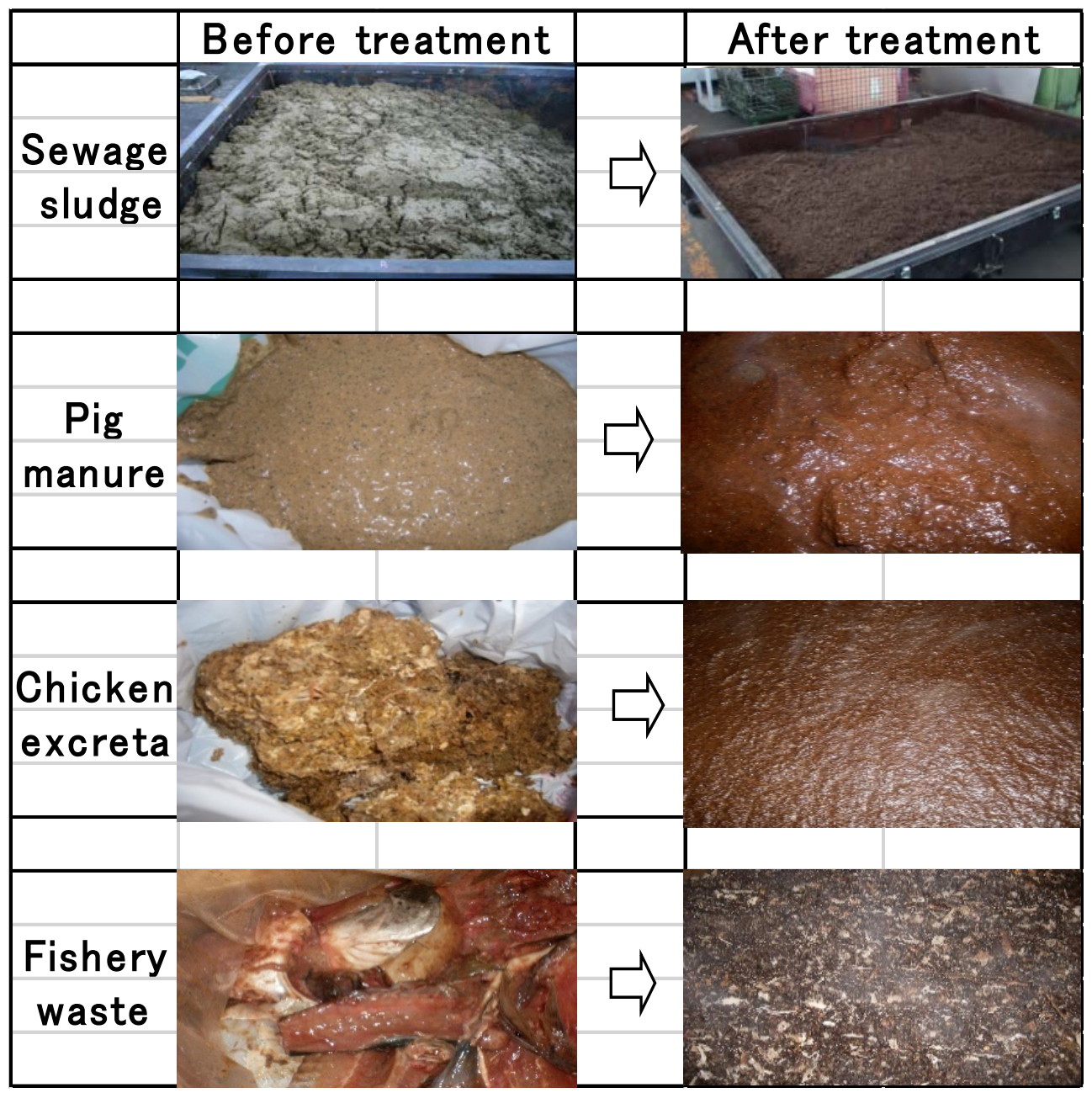

Figure 3: Sewage sludge, pig manure, chicken excreta, and fishery waste before and after the treatment by the subcritical water treatment technology. 


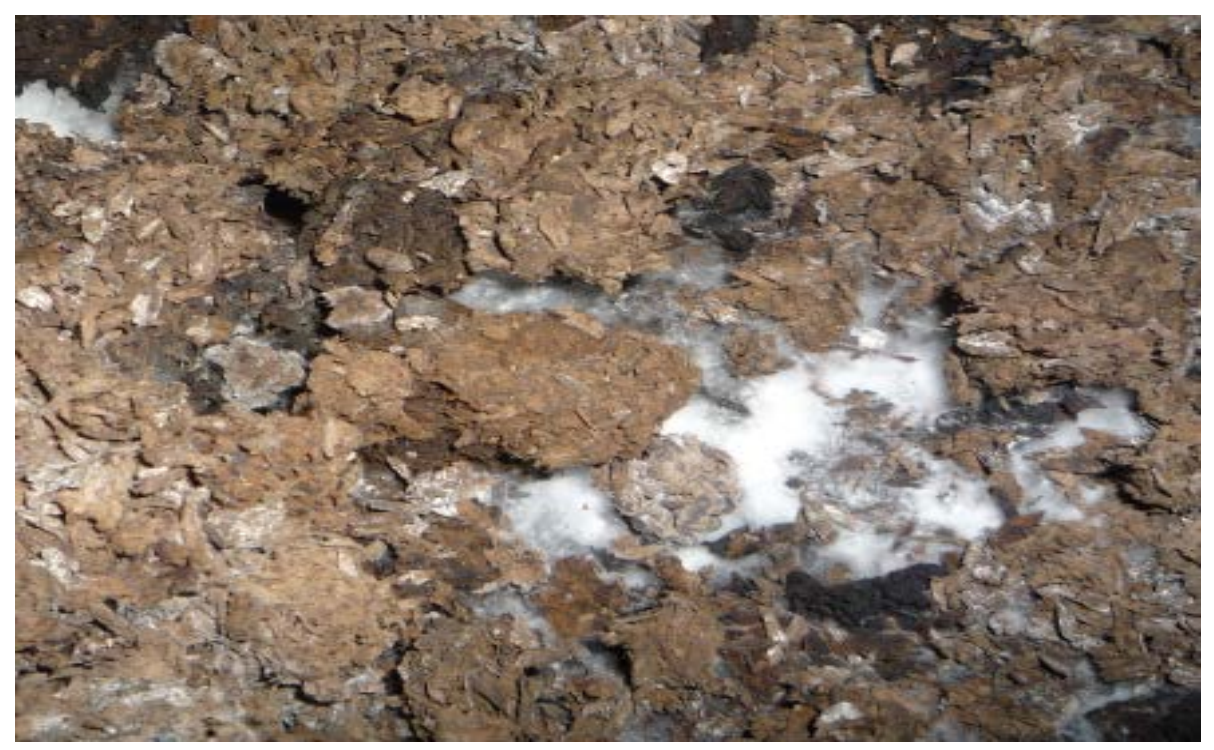

Figure 4: Chicken excreta partly covered by a white patch of actinomyces growth after treatment.

Table 1 shows the chemical content analyses of the sewage sludge, before and after treatment. For example, the content results of the treated sewage sludge were: water content 60.97\%, pH 4.16, organic content 87.33\%, T-N 0.69\%, $\mathrm{P}_{2} \mathrm{O}_{5}$ 0.705\%, K 3,150 mg/kg, Ca $70,500 \mathrm{mg} / \mathrm{kg}, \mathrm{Mg} 3,090 \mathrm{mg} / \mathrm{kg}$, and Na 1,150 mg/kg. Tables 2 and 3 show the chemical content of pig manure and chicken excreta after treatment. These tables show that the chemical results of the residual material are relevant for that of a fertilizer in China satisfying the Chinese standards as shown in Table 4, Table 5, and Table 6 [3]-[5] (Table 5 also shows the sewage sludge use standards for farmland in Japan). These results demonstrate a very good distribution of elements for a general organic fertilizer and it was verified to be pathogen free, as well as free of hazardous chemicals with heavy metals low enough to satisfy the Chinese standards for continuous applications on agricultural lands as shown in Tables 1-3. In China, heavy metal contamination is regulated and managed by sewage authorities. The concentrations of heavy metals in treated sewage sludge by the SCWT reactor, were reduced to less than the designated safety levels.

Table 7 shows the chemical content analyses of fishery waste after treatment. As mentioned above, fifty five percent of a fish can be eaten, but the remaining $45 \%$ includes the head, spines, and abdomen, which cannot be eaten, so these are generally disposed of by incineration. However, this waste material contains significant components that are good for health such as DHA and EPA. The meat is decomposed into useful amino acids, and the bone comes out in a powder form of calcium phosphate. Due to the strong hydrolysis nature and the powerful ability to extract oil in the subcritical water reactor process, most of the fish bone materials are converted into useful substances such as amino acids including cystine and alanine, and fatty acids including EPA/DHA. Lipids extracted from fish or fish bones are degraded by oxygen, temperature and light. Therefore, they need to be removed promptly and be stored in cold conditions (e.g. in a refrigerated store room) prior to further use after the process of extraction. 
Table 1: Analyses of sewage sludge before and after treatment.

\begin{tabular}{|l|c|c|}
\hline Examination items & Before treatment & After treatment \\
\hline Water content (\%) & 84.83 & 60.97 \\
\hline pH & 6.36 & 4.16 \\
\hline Organic Matter (\%) & 70.87 & 87.33 \\
\hline Ash (\%) & 29.13 & 12.67 \\
\hline Nitrogen (\%) & 0.88 & 0.69 \\
\hline Phosphorus $\left(\mathrm{P}_{2} \mathrm{O}_{5}\right)(\%)$ & 0.923 & 0.705 \\
\hline Potassium $\left(\mathrm{K}_{2} \mathrm{O}\right)(\mathrm{mg} / \mathrm{kg})$ & $1.16 \times 10^{4}$ & $3.15 \times 10^{3}$ \\
\hline Sodium $(\mathrm{mg} / \mathrm{kg})$ & $3.22 \times 10^{3}$ & $1.15 \times 10^{3}$ \\
\hline Calcium $(\mathrm{mg} / \mathrm{kg})$ & $2.04 \times 10^{4}$ & $7.05 \times 10^{4}$ \\
\hline Magnesium $(\mathrm{mg} / \mathrm{kg})$ & $1.12 \times 10^{4}$ & $3.09 \times 10^{3}$ \\
\hline Iron $(\mathrm{mg} / \mathrm{kg})$ & $1.10 \times 10^{4}$ & $4.19 \times 10^{3}$ \\
\hline Copper $(\mathrm{mg} / \mathrm{kg})$ & 262 & 76 \\
\hline Zinc $(\mathrm{mg} / \mathrm{kg})$ & 976 & 300 \\
\hline Aluminum $(\mathrm{mg} / \mathrm{kg})$ & $1.60 \times 10^{4}$ & $4.90 \times 10^{3}$ \\
\hline Beryllium (mg/kg) & $<0.10$ & $<0.10$ \\
\hline Lead (mg/kg) & 30.4 & 20.4 \\
\hline Arsenic (mg/kg) & 6.77 & 1.6 \\
\hline Mercury (mg/kg) & 7.75 & 0.88 \\
\hline Cadmium (mg/kg) & 0.52 & 0.097 \\
\hline Chromium (mg/kg) & 42 & 22.4 \\
\hline Bacillus species (cfu/g) & $2.13 \times 10^{9}$ & Undetected \\
\hline Fungi (cfu/g) & $1.56 \times 10^{5}$ & Undetected \\
\hline Actinomycetes species $(\mathrm{cfu} / \mathrm{g})$ & $4.56 \times 10^{6}$ & Undetected \\
\hline
\end{tabular}

Table 2: Analyses of pig manure after treatment.

\begin{tabular}{|l|c|}
\hline Examination items & After treatment \\
\hline Water content $(\%)$ & 27 \\
\hline $\mathrm{pH}$ & 8.2 \\
\hline Organic Matter $(\%)$ & 82 \\
\hline Nitrogen $(\%)$ & 2.2 \\
\hline Phosphorus $\left(\mathrm{P}_{2} \mathrm{O}_{5}\right)(\%)$ & 4.3 \\
\hline Potassium $\left(\mathrm{K}_{2} \mathrm{O}\right)(\mathrm{mg} / \mathrm{kg})$ & 3.8 \\
\hline Lead $(\mathrm{mg} / \mathrm{kg})$ & 14 \\
\hline Arsenic $(\mathrm{mg} / \mathrm{kg})$ & 7 \\
\hline Mercury $(\mathrm{mg} / \mathrm{kg})$ & 0.4 \\
\hline Cadmium $(\mathrm{mg} / \mathrm{kg})$ & 0.1 \\
\hline Chromium $(\mathrm{mg} / \mathrm{kg})$ & 2 \\
\hline NPK content $(\%)$ & 10.3 \\
\hline
\end{tabular}


Table 3: Analyses of chicken excreta after treatment.

\begin{tabular}{|l|c|}
\hline Examination items & After treatment \\
\hline Water content $(\%)$ & 15.6 \\
\hline $\mathrm{pH}$ & 7.5 \\
\hline Organic Matter (\%) & 89.3 \\
\hline Nitrogen $(\%)$ & 4.8 \\
\hline Phosphorus $\left(\mathrm{P}_{2} \mathrm{O}_{5}\right)(\%)$ & 2.7 \\
\hline Potassium $\left(\mathrm{K}_{2} \mathrm{O}\right)(\mathrm{mg} / \mathrm{kg})$ & 0.9 \\
\hline Calcium $(\mathrm{mg} / \mathrm{kg})$ & 3.1 \\
\hline Magnesium $(\mathrm{mg} / \mathrm{kg})$ & 0.3 \\
\hline Copper $(\mathrm{mg} / \mathrm{kg})$ & $<25$ \\
\hline Zinc $(\mathrm{mg} / \mathrm{kg})$ & $<137$ \\
\hline Lead $(\mathrm{mg} / \mathrm{kg})$ & $<10$ \\
\hline Nickel $(\mathrm{mg} / \mathrm{kg})$ & $<5.0$ \\
\hline Arsenic $(\mathrm{mg} / \mathrm{kg})$ & $<10.0 \mathrm{mg} / \mathrm{kg}$ \\
\hline Mercury $(\mathrm{mg} / \mathrm{kg})$ & $<0.2 \mathrm{mg} / \mathrm{kg}$ \\
\hline Cadmium $(\mathrm{mg} / \mathrm{kg})$ & $<0.5 \mathrm{mg} / \mathrm{kg}$ \\
\hline Chromium $(\mathrm{mg} / \mathrm{kg})$ & $<10 \mathrm{mg} / \mathrm{kg}$ \\
\hline C/N Ratio & 10.7 \\
\hline
\end{tabular}

Table 4: Soil environmental standards of China (GB15618-1995).

\begin{tabular}{|c|l|c|c|c|c|c|c|}
\hline \multirow{2}{*}{ No. } & Element & Unit & $\begin{array}{c}1 \text { 1st } \\
\text { class }\end{array}$ & \multicolumn{3}{|c|}{ 2nd class (farmland) } & $\begin{array}{c}\text { 3rd class } \\
\text { (forest } \\
\text { land) }\end{array}$ \\
\cline { 3 - 8 } & & $\begin{array}{c}\text { Natural } \\
\text { Back- } \\
\text { ground }\end{array}$ & $\begin{array}{c}\mathrm{pH} \\
<6.5\end{array}$ & $\begin{array}{c}\mathrm{pH} \\
=6.5-7.5\end{array}$ & $\begin{array}{c}\mathrm{pH} \\
>7.5\end{array}$ & $\begin{array}{c}\mathrm{pH} \\
>6.5\end{array}$ \\
\hline 1 & Cadmium & $\mathrm{mg} / \mathrm{kg}$ & 0.2 & 0.3 & 0.3 & 0.6 & 1 \\
\hline 2 & Mercury & $\mathrm{mg} / \mathrm{kg}$ & 0.15 & 0.3 & 0.5 & 1 & 1.5 \\
\hline 3 & Arsenic (paddy field) & $\mathrm{mg} / \mathrm{kg}$ & 15 & 30 & 25 & 20 & 30 \\
\hline 4 & Arsenic (field) & $\mathrm{mg} / \mathrm{kg}$ & 15 & 40 & 30 & 25 & 40 \\
\hline 5 & Copper (farmland) & $\mathrm{mg} / \mathrm{kg}$ & 35 & 50 & 100 & 100 & 400 \\
\hline 6 & Copper (orchard) & $\mathrm{mg} / \mathrm{kg}$ & - & 150 & 200 & 200 & 400 \\
\hline 7 & Lead & $\mathrm{mg} / \mathrm{kg}$ & 35 & 250 & 300 & 350 & 500 \\
\hline 8 & Chromium (paddy field) & $\mathrm{mg} / \mathrm{kg}$ & 90 & 250 & 300 & 350 & 400 \\
\hline 9 & Chromium (field) & $\mathrm{mg} / \mathrm{kg}$ & 90 & 150 & 200 & 250 & 300 \\
\hline 10 & Zinc & $\mathrm{mg} / \mathrm{kg}$ & 100 & 200 & 250 & 300 & 500 \\
\hline 11 & Nickel & $\mathrm{mg} / \mathrm{kg}$ & 40 & 40 & 50 & 60 & 200 \\
\hline
\end{tabular}


Table 5: Sewage sludge use standards for farmland of China (CJ/T 309-2009) and for that of Japan.

\begin{tabular}{|c|l|c|c|c|c|}
\hline \multirow{2}{*}{ No. } & \multirow{2}{*}{ Element } & \multicolumn{2}{|c|}{$\begin{array}{c}\text { Standard value in } \\
\text { China (mg/kg) }\end{array}$} & \multicolumn{2}{|c|}{$\begin{array}{c}\text { Standard value in Japan } \\
\text { (mg/kg) }\end{array}$} \\
\cline { 3 - 6 } & A class & B class & $\begin{array}{c}\text { Fertilizers } \\
\text { Regulation } \\
\text { Act }\end{array}$ & $\begin{array}{c}\text { Soil } \\
\text { Environmental } \\
\text { Standard }\end{array}$ \\
\hline 1 & Cadmium & $<3$ & $<15$ & $<5$ & 150 \\
\hline 2 & Mercury & $<3$ & $<15$ & $<2$ & 15 \\
\hline 3 & Lead & $<300$ & $<1,000$ & $<100$ & 150 \\
\hline 4 & Chromium & $<500$ & $<1,000$ & $<500$ & 250 \\
\hline 5 & Arsenic & $<30$ & $<75$ & $<50$ & 150 \\
\hline 6 & Nickel & $<100$ & $<200$ & $<300$ & - \\
\hline 7 & Zinc & $<1,500$ & $<3,000$ & - & - \\
\hline 8 & Copper & $<500$ & $<1,500$ & - & - \\
\hline
\end{tabular}

Table 6: Sewage sludge standard for land disposal in China.

\begin{tabular}{|c|l|c|}
\hline No. & Element & Standard value $(\mathrm{mg} / \mathrm{kg})$ \\
\hline 1 & Cadmium & $<20$ \\
\hline 2 & Mercury & $<25$ \\
\hline 3 & Lead & $<1,000$ \\
\hline 4 & Chromium & $<1,000$ \\
\hline 5 & Arsenic & $<75$ \\
\hline 6 & Nickel & $<200$ \\
\hline 7 & Zinc & $<4,000$ \\
\hline 8 & Copper & $<1,500$ \\
\hline 9 & Total cyanides $(\mathrm{mg} / \mathrm{kg}-\mathrm{DS})$ & $<10$ \\
\hline
\end{tabular}

Table 7: Analyses of fishery waste after treatment.

\begin{tabular}{|l|c|}
\hline Examination items & After treatment \\
\hline Water content (\%) & 56.50 \\
\hline Protein (\%) & 24.40 \\
\hline Crude fat (\%) & 9.00 \\
\hline Cellulose (\%) & 0.20 \\
\hline Ash (\%) & 9.60 \\
\hline Nitrogen (\%) & 0.30 \\
\hline Calcium (\%) & 3.15 \\
\hline DHA (\%) & 1.38 \\
\hline Amino acid (\%) & 23.31 \\
\hline
\end{tabular}




\section{CONCLUSIONS}

In this study, demonstration experiments with sewage sludge, livestock manure, and fishery waste were undertaken using the subcritical water treatment (SCWT) reactors by varying temperature, pressure and time. From the results, the conditions best for treating sewage sludge were a temperature of $185^{\circ} \mathrm{C}$ and a pressure of $1.2 \mathrm{MPa}$, and a reaction time of 30 minutes. Pig manure and chicken excreta were treated using similar conditions. The conditions for treating fishery waste were found to be a temperature of $140^{\circ} \mathrm{C}$ and a pressure of $1.0 \mathrm{MPa}$, and a reaction time of 10 minutes. The content analysis results of the treated sewage sludge and livestock manure showed that these materials were appropriate for material to be used as a fertilizer. The results show a good range of elements of a general organic fertilizer, and it was confirmed to be pathogen free, as well as free of hazardous chemicals with heavy metals low enough to satisfy standards for continuous applications on agricultural lands. Furthermore, the content analysis of the treated fishery waste gave results appropriate for materials to be used as a fertilizer, feed for livestock and components for health products such as DHA and EPA.

\section{ACKNOWLEDGEMENT}

The authors are grateful to G-8 International Trading LTD for providing valuable data.

\section{REFERENCES}

[1] The Basic Law for Establishing the Recycling-based Society, Ministry of the Environment, Online. http://www.env.go.jp/recycle/low-e.html. Accessed on: 28 Jan. 2018.

[2] Systematization of Resource/Energy Recycling; Ministry of Land, Infrastructure, Transport and Tourism, Online. http://www.mlit.go.jp/crd/sewerage/policy/09.html. Accessed on: 28 Jan. 2018.

[3] Miyashiro. T., Multipurpose resource recycling of wastes using subcritical water reaction and safety evaluation, Doctor thesis, The University of Tsukuba, 2012.

[4] Environmental quality standard for soils, Standards Press of CHINA, 1996.

[5] Disposal of sludge from municipal wastewater treatment plant - control standards of agricultural use, Standards Press of CHINA, 2009. 